\title{
Immunoprophylaxis to limit a hepatitis B epidemic among women undergoing in vitro fertilization
}

\begin{abstract}
Pia M Grosheide, Helena C van Osand, Solko W Schalm*, Rudolf A. Heıtınk ${ }^{\dagger}$

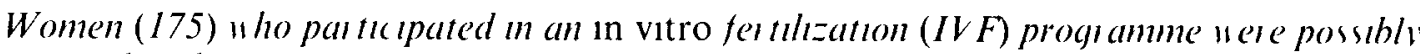
exposed to hepatits, $B$ vulus Later 1 became evident that 79 "lomen had a hepatits $B$ infection, 49 were exposed but not infected and 47 were not exposed Hepatits $B$ immunoglobulin $(\mathrm{HBIg})$ and recombinant hepattts $B$ vaccine (HBvaxDNA) were offered to all women and partners except for those w'th established hepatits $B$ Women were given an 'intensive' schedule of $H B I g(0,1$ months $)$ and vaccine $(0,1,2,6$ months $)$ Spouses recelved $H B I g(0,1$ months $)$ and vaccine $(0,1,6$ months $)$ Blood samples were taken at the time of diagnosis of the $H B V$ epidemic and at regular intervals Hospital personnel immunized according to the regular schedule $(0,1$ and 6 months) with HBvaxDNA but without HBIg served as controls During the observation period of 7 months antl- $\mathrm{HBc}$ seroconversion was not observed At month 7 the seroconversion rate for males was $89 \%$, significantly lower than that for females $(100 \%)$ Intermediate rates were found for the control groups $(94 \%)$ Significant differences in geometric mean titre between IVF-treated patlents and controls were, however, observed at month $7\left(551 \mathrm{mIU} \mathrm{ml^{-1 }}\right.$ for female patlents versus $1582 \mathrm{mIU} \mathrm{ml}^{-1}$ for their controls and $171 \mathrm{mIU} \mathrm{ml}^{-1}$ for males versus $899 \mathrm{mIU} \mathrm{ml}^{-1}$ for their controls) Possible explanations for the low reactivity to $\mathrm{HBs} \mathrm{Ag}$ vaccine are discussed
\end{abstract}

Keywords Hepatıti, B postexposure prophylaxis passive active immunization

\section{INTRODUCTION}

In early March 1988 the Unıversity Hospital Dijkzıgt was confronted with a hepatitis B epidemic in women who had undergone in vitro fertilization ${ }^{12}$ All women $(n=175)$ who had undergone in vitro fertilization (IVF) since November 1987 but were without signs of hepatitis $B$ virus (HBV) infection at first screening, as well as their sexual partners, were offered passive active immunization ${ }^{3}$

The rationale for starting passive active immunization 6-18 weeks after HBV-exposure was to modify infection in females and to prevent infection in males All women followed an 'intensive' immunization scheme consisting of hepatitis B immunoglobulin (HBIg) on day 1 and 1 month later and recombinant vaccine on day 1 and 1,2 and 6 months later Male partners who may have been exposed to HBV for several weeks also received HBIg on day 1 and 1 month later and recombinant vaccine on day 1 and 1 and 6 months later

In this study the levels of $\mathrm{HBV}$ protective antibodies (ant1-HBs $\geqslant 10 \mathrm{mIU} \mathrm{ml}^{-1}$ ) induced by passive active immunization were examined An explanation was

Department of Internal Medıcıne II, *Department of Obstetrıcs and Gynaecology, Unıversity Hospıtal Dıjkzıgt and ${ }^{\dagger}$ Department of Virology, Erasmus University, Dr Molewaterpleın 50 , 3000 DR Rotterdam, The Netherlands 'To whom correspondence should be addressed (Recerved 14 January 1991, revised 3 May 1991, accepted 7 May 1991) sought for the relatively poor immune response in the IVF population

\section{MATERIALS AND METHODS}

\section{Patients and controls}

From 2 November 1987 untıl 21 January 1988175 women undergoing IVF might have been exposed to hepatitis B virus Tissue culture medium supplemented with $75 \%$ heat-1nactivated $\left(30 \mathrm{~min} 56^{\circ} \mathrm{C}\right)$ human serum, which was used for pre-embryo cultures or other procedures during in vitro fertilization, seemed to be the most probable source of infection The human serum was regularly pooled from blood samples of 15-20 pregnant women All donors were individually screened for hepatıtıs B virus Due to a breakdown in communication between the outpatient clinic of the Department of Obstetrics and the IVF laboratory, the results of the routine screening of sera from pregnant women for HBsAg temporarily did not reach the IVF laboratory and an HBV-positive serum was apparently included in the pooled serum On 2 March 1988 the epidemic was discovered by reports on three cases of jaundice All women at risk and their partners were immediately requested to visit the University Hospital Dijkzigt for medical examination Blood samples were obtained from 174 potentially exposed women and 167 sexual partners and preventive measures were advised These measures 
Table 1 Overview of the vaccination groups after possible exposure to hepatitis $B$

\begin{tabular}{|c|c|c|c|c|c|}
\hline & \multicolumn{4}{|c|}{ Group } & \multirow[b]{3}{*}{ Total } \\
\hline & 1 & 2 & 3 & 4 & \\
\hline & \multicolumn{2}{|c|}{ Females } & \multicolumn{2}{|c|}{ Males } & \\
\hline Total & $128(27)$ & $47(14)$ & 79 & 96 & 350 \\
\hline Excluded at presentation & $32(13)$ & 0 & 1 & 8 & 41 \\
\hline Vaccination started & $96(14)$ & $47(14)$ & 78 & 88 & 309 \\
\hline Excluded after screening ${ }^{\circ}$ & $58(8)$ & $6(1)$ & 4 & 11 & 79 \\
\hline Vaccination contınued & $38(6)$ & $41(13)$ & 74 & 77 & 230 \\
\hline Vaccination complete & $29(6)$ & $30(8)$ & 56 & 65 & 180 \\
\hline Blood sample month 7 & $24(3)$ & $29(8)$ & 43 & 52 & 148 \\
\hline Evaluated month $7^{\circ}$ & $22(3)$ & $28(8)$ & 43 & 52 & 145 \\
\hline
\end{tabular}

Figures in parentheses indicate number of women pregnant

Clınıcal hepatıtıs pregnant and $\mathrm{HBsAg}+$ known ımmune response after vaccination no serum avallable, "markers of past or present HBV infection with or without confirmation by pre-treatment sera, ${ }^{c}$ see text for reasons for exclusion

included hygiene, use of condoms during sexual intercourse and passive active immunization

Analysis of the incidence of HBV infection in 7 day cohorts of in vitro fertilization treatment finally revealed that the period of infectious exposure only extended from 2 November to 13 December 1987 (period 1), this period concided with the use of one of the two batches of pooled serum used in tissue culture None of the women treated from 14 December 1987 to 21 January 1988 (period 2) developed signs of a hepatitıs B infection

Of the total of 175 women, 128 were exposed to the infectious batch of pooled serum, the remainıng 47 women were not exposed to infectious culture medium Of the 128 women exposed in period 1, 30 had clinical signs of HBV or were HBsAg-positive and pregnant at first presentation One woman did not deliver serum and another woman was protected by previous vaccination Therefore immunization was started in 96 women Due to the presence of markers of hepatitus $B$ in the pre-IVF serum ( 9 cases) or in serum taken at first presentation (49 cases), immunization was stopped in 58 of the 96 women (Table 1) The remaining 38 women contınued immunization and may be characterized as exposed but not infected (group 1) A second group of vaccinees (group 2) is composed of women who recelved IVF treatment in period 2, the information that the culture medium used in period 2 was not infectious became avallable about 2 months after immunization had started

Immunization was completed in the large majority of women The other immunization groups comprised the partners The spouses of $79 \mathrm{HBV}$ infected women by IVF treatment were labelled as group 3 The spouses of 49 non-infected women from period 1 together with the spouses of 47 women tredted in period 2 comprised group 4 Further detals of the four immunization groups are given in Tables 1 and 2 The control groups, hospital personnel immunized in the same period, consisted of 84 females (group 5) and 53 males (group 6)

\section{Immunization}

Hepatitis B immunoglobulin $15 \mathrm{ml}, 100-200$ IU antl$\mathrm{HB}, \mathrm{ml}^{-1}$. Central Laboratory of the Netherlands Red Cross Blood Transfusion Service (CLB)) and hepatitis B recombınant vaccine $(10 \mu \mathrm{g}$. HBvaxDNA, Merck Sharp \& Dohme, West Point, PA. USA) were admınıstered to all women except those with clinical hepatitis or pregnant women with HBsAg-positıvity, as determined by rapid blood testing with the reversed passive haemagglutination assay (Hepatest, Wellcome Laboratories, Beckenham, UK) at first presentation A second dose of HBIg was given 1 month later Additional doses of vaccine were admınıstered 1,2 and 6 months later $\mathrm{HBIg}$ and vaccine were discontınued as soon as HBV markers not due to $\mathrm{HBIg}$ or vaccine were detected in the serum

Male partners received HBIg on day 1 and 1 month later and HBvaxDNA $(10 \mu \mathrm{g})$ on day 1 and 1 and 6 months later Immunization was discontinued when vaccinees were found to be positive for $\mathrm{HBsAg}$, ant1- $\mathrm{HBc}$ or ant1-HBs at screening After 4 months, partners of HBV-positive women (group 3) received an additional dose of HBIg if the ant1-HBs titre was below $20 \mathrm{mIU} \mathrm{ml}^{-1}$ and likely to fall below $10 \mathrm{mIU} \mathrm{ml}^{-1}$ before the booster vaccine injection at 6 months

Hospital personnel, who served as controls, received HBvaxDNA $(10 \mu \mathrm{g})$ from the same lot according to the regular schedule on day 1 and 1 and 6 months later without HBIg (Table 2) HBIg was administered by injection $1 \mathrm{~m}$ into the buttock, HB-vaccine was injected $1 \mathrm{~m}$ into the deltord muscle

\section{Blood sampling and laboratory methods}

Pre-1mmunization serum samples were obtained in March 1988 For females follow-up blood samples were drawn 1,2,6 and 7 months after the first vaccine injection For males, blood samples were taken after 1, 4, 6 and 7 months All pre-immunization samples from groups 1-4 as well as follow-up samples were tested for $\mathrm{HBsAg}$, ant1-HBc and ant1-HBs Blood samples from controls were tested for ant1-HBc and ant1-HBs after 7 months

Blood samples were tested for $\mathrm{HBsAg}$ and ant1- $\mathrm{HBc}$ by enzyme immunoassay (Abbott Laboratories, Chicago, IL, USA) Ant1-HBs was tested by radio immunoassay (Ausab, Abbott Laboratories) and quantıfied using the WHO standard preparation ${ }^{4}$ A protective anti-HBs level was defined as ant1-HBs concentration $\geqslant 10 \mathrm{mIU} \mathrm{ml}^{-1}$, in the absence of other HBV markers

\section{Statistical calculations}

Statistical differences in protective antı-HBs levels were

Table 2 Characteristics of IVF treated females, partners and controls completıng hepatitıs $B$ vaccination

\begin{tabular}{|c|c|c|c|c|c|}
\hline \multirow[b]{3}{*}{ Group } & \multirow[b]{3}{*}{ No } & \multirow{3}{*}{$\begin{array}{l}\text { Mean age } \\
\text { (range) }\end{array}$} & \multicolumn{3}{|c|}{$\begin{array}{l}\text { Vaccination schedule } \\
\text { in months }\end{array}$} \\
\hline & & & $\mathrm{HBIg}$ & $\mathrm{HB}$ & xDNA \\
\hline & & & 0,1 & 0,16 & 0,126 \\
\hline 1 Women exposed & 22 & $35(2839)$ & $x$ & & $x$ \\
\hline $\begin{array}{l}2 \text { Women } \\
\text { not exposed }\end{array}$ & 28 & $35(24-40)$ & $x$ & & × \\
\hline $\begin{array}{l}3 \text { Partners } \\
\text { HBV infection }\end{array}$ & 43 & $39(32-57)$ & $x^{\pi}$ & $x$ & \\
\hline $\begin{array}{l}4 \text { Partners no } \\
\text { HBV infection }\end{array}$ & 52 & $38(29-48)$ & $x^{b}$ & $x$ & \\
\hline 5 Female controls & 84 & $34(22-57)$ & & $x$ & \\
\hline 6 Male controls & 53 & $35(2261)$ & & $x$ & \\
\hline
\end{tabular}

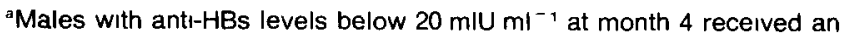
additional HBIg injection

${ }^{b}$ Sexual partner exposed but not infected $(n=20)$ and sexual partner not exposed $(n=32)$ 
calculated with $95 \%$ confidence intervals for the difference between two proportions The geometric mean titres (GMTs) for all vaccinees in various groups were compared, after logarithmic transformation by the Student's $t$-test

\section{RESULTS}

Of the 230 individuals who contınued immunization after initial screening (79 females, 151 males), a total of 180 vaccinees ( 59 females, 121 males) completed the immunization programme Postimmunization blood samples were obtained in 148 cdses (53 females, 95 males) at month 7 Three women ( 2 in group 1 and 1 in group 2) were excluded from evaluation because they showed more than $10 \mathrm{mIU} \mathrm{ml}^{-1}$ anti-HBs on day 1 , although ant1-HBc tests were negative

Of the 38 females exposed to HBV (group 1), three did not show up for further treatment after month 1 At that time, they were all negative for both $\mathrm{HBsAg}$ and antr-HBc Two females did not return for follow-up at month 6 but were HBsAg-negatıve and antı-HBs-positıve at month 4, another nine women who were HBsAgnegative at month 6 with antı-HBs $\geqslant 10 \mathrm{mIU} \mathrm{ml}^{-1}$ did not appear for follow-up at month 7 Of the 37 women who delivered healthy living children ${ }^{5}$, nine received one dose of HBIg and HBvaxDNA during pregnancy and 14 received full immunization durıng pregnancy No adverse reactions to $\mathrm{HBIg}$ or vaccine were reported during the observation period of 7 months for vaccinees with or without HBV markers at the time of first presentation, except for one pregnant vaccinee who had a spontaneous abortion two days after initial immunization

The rate of development of protective antıbody levels $\left(\geqslant 10 \mathrm{mlU} \mathrm{ml}^{-1}\right)$ is shown in Table 3 One month after the first dose of $\mathrm{HBIg}$ and vaccine, protective antıbodies were found in $99 \%(203 / 205)$ of the vaccinees Ant1-HBs levels were inadequate in two cases (one female in group 2 with $8 \mathrm{mIU} \mathrm{ml}^{-1}$ and one male in group 3 with no detectable anti-HBs) At month 2 protective antibody levels were demonstrated in all females tested At month $423 \%$ of the men of group 3 and $20 \%$ of those of group 4 were unprotected (antl-HBs $<10 \mathrm{mIU} \mathrm{ml}^{-1}$ ) At month 6 protective ant1-HBs levels were measured significantly less often in group 4 males $(48 \%, 95 \%$ CI $36-60 \%)$ compared with both groups 1 and $2(87 \%, 95 \% \mathrm{CI}$ $75-99 \%)$ and group $3(81 \%, 95 \%$ CI $71-91 \%)$ due to the fact that the ant1-HBs level of the majority of the

Table 3 Development of protectıve antıbody levels (antı-HBs $\geqslant 10 \mathrm{mlU} \mathrm{ml}^{-1}$ ) after vaccination

\begin{tabular}{|c|c|c|c|c|c|}
\hline \multirow[b]{3}{*}{ Group } & \multirow[b]{3}{*}{ Sex } & \multicolumn{4}{|c|}{ Percentage with antı-HBs $\geqslant 10 \mathrm{mlU} \mathrm{ml}^{-1}$} \\
\hline & & \multicolumn{4}{|c|}{ Month } \\
\hline & & 1 & $2 / 4^{a}$ & 6 & 7 \\
\hline 1 & Female & $100(33)$ & $100(33)$ & $87(31)$ & $100(22)$ \\
\hline 2 & Female & $97(39)$ & $100(39)$ & $87(31)$ & $100(28)$ \\
\hline 3 & Male & $98(61)$ & $77(57)$ & $81(58)$ & $93(43)$ \\
\hline 4 & Male & $100(72)$ & $80(64)$ & $48(68)$ & $86(52)$ \\
\hline 5 & Female & & & & $94(84)$ \\
\hline 6 & Male & & & & 94 (53) \\
\hline
\end{tabular}

${ }^{a}$ Blood sample females at month 2 , males at month 4

Figures in parentheses indicate number of blood samples tested
Table 4 Levels of antı-HBs after HB-vaccination expressed as geometrıc mean titre in $\mathrm{mIU} \mathrm{ml}^{-1}$ calculated for vaccınees with antı-HBs $\geqslant 1 \mathrm{mlU} \mathrm{ml}^{-1}$

\begin{tabular}{|c|c|c|c|c|c|}
\hline \multirow[b]{3}{*}{ Group } & \multirow[b]{3}{*}{ Sex } & \multicolumn{4}{|c|}{ GMT in $\mathrm{mlU} \mathrm{m}^{-1}$} \\
\hline & & \multicolumn{4}{|c|}{ Month } \\
\hline & & 1 & $24^{2}$ & 6 & 7 \\
\hline 1 & Female & $35(33)$ & $45(33)$ & $30(29)$ & $396(22)$ \\
\hline 2 & Female & $35(38)$ & 47 (39) & $44(30)$ & 715 (28) \\
\hline 3 & Male & $34(60)$ & $16(56)$ & $16(56)$ & $150(43)$ \\
\hline 4 & Male & $37(72)$ & $19(65)$ & $9(65)$ & $190(50)$ \\
\hline 5 & Female & & & & $1582(80)$ \\
\hline 6 & Male & & & & $899(50)$ \\
\hline
\end{tabular}

Blood sample females at month 2 , males at month 4 Figures in parentheses indicate number of blood samples with anti-HBs $\geqslant 1 \mathrm{mlU} \mathrm{ml}{ }^{\prime}$ antı-HBs

$\rho$ values for differences in GMT at month 7 group 1 versus 2, not significant, group 3 versus 4 , not significant, group 5 versus 6 , not significant, group $1+2\left(\mathrm{GMT}=551 \mathrm{mlU} \mathrm{ml}^{-1}\right)$ versus $3+4 \quad(\mathrm{GMT}=$ $\left.171 \mathrm{mlU} \mathrm{ml}^{-1}\right), p<0002$, group $1+2$ versus $5, p=0001$, group $3+4$ versus $6, p<0001$

vaccinees in group 4 remained just below the arbitrarily chosen level of $10 \mathrm{mIU} \mathrm{ml}^{-1}$ (see GMTs at month 6 in Table 4) For group 3 the higher rate of $81 \%$ was probably due to the extra dose of HBIg given at month 4 to 25 spouses with anti-HBs titres $<20 \mathrm{mIU} \mathrm{ml}^{-1}$ Protective ant1-HBs levels after completion of vaccination at month 7 were found in all women of groups 1 and $2(100 \%)$ whereas the percentage of males in groups 3 and 4 together $(n=95)$ with protective antibodies at month 7 was $89 \%(95 \% \mathrm{CI} \quad 83-95 \%)$

Table 4 shows the geometric mean titres of ant1-HBs for the various groups Antibody levels of $\approx 35 \mathrm{mIU} \mathrm{ml}^{-1}$ at month 1 probably reflect the first dose of $\mathrm{HBIg}$ in groups 1-4 Titres rose to about $45 \mathrm{mIU} \mathrm{ml}^{-1}$ at month 2 for women receiving two doses of HBIg and vaccine

At month 4, after two doses of HBIg and vaccine, the GMTs for groups 3 and 4 were 16 and $19 \mathrm{mIU} \mathrm{ml}^{-1}$ ant1-HBs, respectively $A$ significant increase in antı-HBs was not observed until after the booster dose was given At month 7 the geometric mean titres of ant1-HBs were significantly lower for all IVF groups compared with their control groups (group 1 and 2 versus $5 p<005$, group 3 and 4 versus $6 \quad p<0001$ )

Since selection of vaccinees due to loss to follow-up may have occurred, the GMT levels of all vaccinees per group were compared with the GMTs of those vaccinees who completed the full immunization scheme in each IVF group No differences in GMTs could be shown at any moment

At month 7 an effect of sex on the immune response to hepatitis $B$ vaccine was indicated by a difference between the female and male groups (IVF groups $1+2$ versus $3+4$ ) The influence of sex was not exhibited by control groups 5 and 6 During the observation period of maximal 7 months anti-HBc seroconversion did not occur in IVF groups All controls were also ant1-HBcnegative after immunization

\section{DISCUSSION}

Hepatitıs B immunoglobulin given after exposure to HBV results in prolongation of the incubation period of the virus and partial protection ${ }^{6-8}$ Beneficial effects of 
postexposure prophylaxis with hepatitis $B$ plasma vaccine have also been demonstrated in adults ${ }^{9-11}$

The combination of HBIg and hepatitis B vaccine for postexposure prophylaxis has been shown to increase protection, meaning fewer clinical and $\mathrm{HBsAg-positive}$ infections, compared with HBIg or HB-vaccine alone ${ }^{12-14}$ Still, although the spouses of acute hepatitis B patients received $\mathrm{HBIg}(5 \mathrm{ml})$ on day 1 and plasma vaccine on day 1 and 1 and 6 months later $(20 \mu \mathrm{g}$, Merck Sharp \& Dohme), $11 \%$ exhibited signs of subclinical infection (ant1-HBc-seroconversion) at the 3 month examination ${ }^{12}$ Repeated injections of HBIg can, however, in the case of accidental exposure to HBV maintain protective levels of ant1-HBs throughout the incubation period ${ }^{715}$ To accelerate the actıve immune response, a vaccination schedule with short injection intervals has been proposed for postexposure prophylaxis ${ }^{16}$

At the discovery of the HBV epidemic the large majority of patients who had undergone in vitro fertilization were offered postexposure prophylaxis In order to modify the course of the disease an 'intensive' schedule of two doses of HBIg and four doses of vaccine was offered to the females To prevent infection in males the standard immunization schedule was used with an additional dose of $\mathrm{HBIg}$ at month $1^{12}$ No $\mathrm{HBV}$ infections, in particular no anti-HBc-seroconversion, were encountered after the start of passive active immunization, however, the protective effect of passive active immunization in this setting cannot be proven in view of the absence of a control group with comparable exposure The absence of infections in partners after the start of immunization is remarkable since they may have been exposed to HBV for several additional days or weeks because 34 women were still $\mathrm{HBeAg}$-positive at the start of immunization Sexual contact is said to be an important mode of transmission ${ }^{1718}$ However sexual exposure appears to be a less efficient mode of Iransmission compared with the percutaneous route and the chance that men will contract hepatitıs B virus during a heterosexual relationship has been estimated to be $<5 \%{ }^{12}$

The overall compliance of couples possibly exposed to HBV appeared to be poor The loss to follow-up may have been due to lack of motivation since exposure to HBV in IVF treatment period 2 had not occurred (groups 2 and 4 ) and vaccinees were regularly informed about their immune status

Passive active immunization of HBsAg-positive or HBV-negative and pregnant vaccinees was practically devord of side-effects It is doubtful whether the abortion 2 days after initial immunization was indeed a direct adverse effect of immunization The first trimester abortion rate after IVF did not differ from that found for the period before HBV contamination of the culture medium was discovered ${ }^{5}$ In fact, immunization of pregnant women in case of high risk for hepatitis B infection is advocated Despite statements of changes in immunity during pregnancy there is little evidence of impairment of cellular immunity in pregnancy The ability to respond to $\mathrm{HBsAg}$ vaccine appeared to be adequate $^{19}$

This study provided the opportunity to determine whether administration of HBIg and recombinant HB-vaccine to adults in a high risk situation consistently led to protective levels of ant1-HBs soon after immunization The first dose of HBIg resulted in a protective level of anti-HBs in all but two cases Subsequent HBIg and vaccine doses did not produce a major increase in antl-HBs levels, except for the booster dose of vaccine at month 6 In fact, administration of a supplementary dose of $\mathrm{HBIg}$ at month 4 was thought to be necessary for the majority of the spouses of HBsAg-positive women

The overall response rate to recombinant $\mathrm{HB}$ vaccine at month 7 was comparable to the response rate for hospital personnel Protective levels of anti-HBs before the booster dose were, however, relatively low (87\% for both female groups and $48 \%$ and $81 \%$ (mean $63 \%$ ) for groups 3 and 4 , respectively, at month 6) compared with other studies of recombinant vaccine ${ }^{20-22}$ in which $\geqslant 93 \%$ of healthy adults had ant1-HBs $\geqslant 10 \mathrm{mIU} \mathrm{ml}^{-1}$ at the time of the booster dose The 'Intensive' immunization schedule with an extra dose of vaccine after 2 months did not appear to accelerate the immune response in females In fact, as far as postexposure prophylaxis is concerned, immunogenicity after admınıstration of recombinant vaccine was very disappointing in this study

Recently, Iwarson recommended an accelerated $1 \mathrm{~m}$ munization schedule that would yield a more rapid antibody response ${ }^{1623}$, such a schedule might be an alternative to HBIg in combination with HB-vaccine in the postexposure situation This study, with a vaccine schedule of 0,2 and 6 weeks, did not yield satisfactory antıbody levels at all, thus emphasızıng the need for $\mathrm{HBIg}$ in postexposure prophylaxis

Known factors that influence the immune response to vaccine include age, sex, antigen dose and number of doses given, site of injection and freezing of the vaccine $^{24} 25$ Sex-related differences in immune response were found for the combined IVF groups but not for controls Age, dose, site of injection and vaccine were the same for the IVF groups and controls Could the large doses of HBIg have interfered with the development of antı-HBs after immunization? Studies of the concurrent administration of HBIg and plasma derived vaccine at one or two occasions showed that the results were similar to those obtained with vaccine alone $e^{92-28}$ Szmuness et $a^{28}$ found that injection of 300 IU of HBIg did not inhibit the anti-HBs response to $20 \mu \mathrm{g}$ doses of $\mathrm{HB}$ vaccine (Heptavdx B, Merck Sharp \& Dohme) in adults In neonates, two major studies have yielded conclusive evidence in favour of the dual approach of postexposure prophylaxis by combination of passive active immunization ${ }^{1329}$ The attack rate for development of the persistent carrier state in neonates of $\mathrm{HBeAg}$ positive $\mathrm{HBsAg}$ carrier mothers was $90 \%$ in untreated groups Both HBIg alone or vaccine alone had $70-80 \%$ efficacy while efficacy rates in the groups given dual prophylaxis were above $90 \%{ }^{13}$ There was no statistically significant advantage from multiple doses as opposed to a single dose of immune globulin in conjunction with hepatitıs B vaccine for efficacy nor for immune response $(\mathrm{GMT})^{29}$

Yet, it cannot be excluded with certainty that an inhibiting effect of HBIg was masked by the high dose of the vaccine used in these studies To investigate this possible interference, Lelie et al ${ }^{30}$ compared the ant1HBs response to a low dose $(06 \mu \mathrm{g})$ of HB heatinactivated vaccine (CLB, $3 \mu \mathrm{g}$ per dose) in health-care workers with and without a single dose simultaneously administered HBIg (500 IU) The ant1-HBs titres of recipients of vaccine alone compared with those with 
HBIg and vaccine were slightly but significantly higher at 3 and 5 months after the first injections but this difference was no longer significant at the time of the booster dose (month 8 ) and thereafter

The use of higher doses of HBIg and the recombinant vaccine with a limited epitope range compared with plasma HBsAg justıfies re-examınation of a possible interaction between doses of $\mathrm{HBIg}$ and the immune response to recombinant vaccine Studies of children receiving recombinant vaccine however did not reveal significant differences when supplemental HBIg was adminıstered $^{31}$

Environmental factors have never been known to influence the immune response to immunization Nevertheless, emotions may have an important effect on the immune system In rats stress has been shown to suppress cellular and humoral immunity ${ }^{32-34}$ For humans in vitro and in vivo studies have demonstrated a direct effect of psychological stress on parameters of immune function ${ }^{34}{ }^{35}$ Several diseases caused by viruses, such as Epsteın-Barr virus, herpes simplex virus type 1 and cytomegalovirus, may be stress-related ${ }^{36}$ The ability of human lymphocytes to respond to an detivating agent declined significantly within 1-2 months of a serious psychological event In some people the responses remained low for an entire year ${ }^{37}$

Without doubt participation in an in vitro fertilization programme and the subsequent discovery of a possible infection with hepatitis B virus can be considered an episode of stress For the majority of vaccinees the period of stress lasted until several months after the first injection of vaccine Therefore the effect of psychological stress on the human immune response may not be ruled out as a possible factor influencing the reactivity to $\mathrm{HBsAg}$

\section{ACKNOWLEDGEMENTS}

The authors are grateful to the nursing staff of the Department of Obstetrics of the Dijkzigt Hospital for their cooperation and the technicians of the Department of Virology for performıng the serological assays

\section{REFERENCES}

1 Alberda, AT, van Os, HC, Zellmaker, GH, Rothbarth, $\mathrm{Ph} \mathrm{H}$, Heıtınk, R A and Schalm, SW Hepatıtıs B-vırusınfectıe bı vrouwen behandeld met in vitro fertilisatie Ned Tijdschr Geneesk 1989, 133, 20-25

2 Quint, W G V, de Bruıın, I, Kruınıng, J and Heıtınk, R A HBV-DNA detection by gene amplification in acute hepatitis $B$ Hepatology $1990,12,653-656$

3 CDC-ACIP Update on hepatıtıs B preventıon Morbıd Mortal Week Rep 1987, 36, 353361

4 World Health Organization Bıological Substances International Standards, Reference Preparations and Reference Reagents Geneva, Switzerland 1982, pp 70-71

5 Van Os, HC, Drogendıı, A C, Fetter, WPF, Heıtınk, RA and Zeilmaker, $\mathrm{GH}$ The influence of contamination of the culturemedium with hepatitis $B$ virus on the outcome of IVF-pregnancies Am J Obstet Gynecol 1991, in press

6 Krugman, S, Overby, LR, Mushawar, IK, Lıng, C M, Frosner, $G \mathrm{G}$ and Deınhardt, $\mathrm{F}$ Studies on natural history and prevention re-examıned $N$ Engl J Med 1979, 300, 101-106

7 Grady, GF, Lee, VA, Prince, AM et al Hepatitıs B ımmune globulın for accidentai exposures among medical personnel final report of a multicenter controlled trial $\mathcal{J}$ Infect Dis 1978, 138, $625-638$

8 Hoofnagle, J H, Seeff, L B, Bales, Z B, Gerety, R J and Tabor, E Passive-active immunity from hepatitis $B$ immune globulın reanalysis of a Veterans Administration Cooperatıve study of needle-stıck hepatitıs Ann Intern Med 1979, 91, 813-818

9 Szmuness, W, Stevens, C E, Zang, E A, Harley, E J and Kellner, A $A$ controlled clinical trial of the efficacy of the hepatıtıs $B$ vaccines (Heptavax B) A fınal report Hepatology 1981, 1, 377-385

10 Francis, D P, Hadler, S C, Thompson, SE et al The prevention of hepatitis $B$ with vaccine report of the Centers of Disease Control multi-center efficacy trial among homosexual men Ann Intern Med 1982, 97, 362-366

11 Szmuness, W, Stevens, C E , Harley, E J et al Hepatıtıs B vaccine in medical staff of hemodialysis units efficacy and sub-type cross-protection $N$ Engl J Med 1982, 307, 1481-1487

12 Papaevangelou, G, Roumelıotou-Krayannis, A, Richardson, S C and Krugman, $S$ Postexposure Immunoprophylaxis of spouses of patients with acute viral hepatitis $B$ Viral Hepatitis $B$ and Liver Disease (Ed Zuckerman, A J) Alan R Liss, Inc, New York, 1988, pp 992-994

13 Beasley, RP, Hwang, LY, Lee, GCY, Lan, C C, Roan, CH, Huang, $F Y$ and Chen, $C L$ Prevention of perinatally transmitted hepatitis $B$ virus infections with hepatitis $B$ immunoglobulin and hepatıtıs B vaccine Lancet 1983, I, 1099-1102

14 Mitsuı, T, Iwano, K, Suzukı, S et al Combıned hepatıtıs B ımmune globulın and vaccine for postexposure prophylaxis of accidental hepatitis $B$ virus infection in hemodialysis staff members comparison with immune globulin without vaccine in historical controls Hepatology 1989, 10, 324-327

15 Beasley, RP, Hwang, $L Y$, Lin, $C C$ et al Hepatitıs $B$ immune globulın (HBIG) efficacy in the interruption of perınatal transmission of hepatitis $B$ virus carrier state initial report of a randomised double-blınd placebo controlled trial Lancet 1981, Ii, 388-393

16 Wahl, $M$, Hermodsson, $S$ and Iwarson, $S$ Hepatitis $B$ vaccination with short dose intervals - a possible alternative for post-exposure prophylaxis? Infection 1988, 16, 229-232

17 Daranı, $M$ and Gerber, $M$ Hepatıtıs $B$ antıgen ın vagınal secretions Lancet 1974, ii, 1008

18 Papaevangelou, G, Roumelıotou-Karayannıs, A, Tassopoulos, N Kolaitis, $N$ and Stathopoulou, $P$ Source of infection due to hepatitis B virus in Greece J Infect Dis 1983, 147, 987-989

19 Stırrat GM Immunology of diseases of pregnancy Immunology of Pregnancy and its Disorders (Ed Stern, $\mathrm{CMH}$ ) Kluwer Academic London 1989, pp 115-143

20 Hollınger, FB, TroIsı, $C L$ and Pepe, PE AntıHBs responses to vaccination with a human hepatıtıs $B$ vaccine made by recombinant DNA technology in yeast $J$ infect $D i s$ 1986, 153, 156-159

21 Jilg, W, Schmidt, M, Zoulek, G, Lorbeer, B, Wilske, B and Deınhardt, $F$ Clınical evaluation of a recombınant hepatitıs $B$ vaccıne Lancet 1984, II, 1174-1175

22 Heıtınk, RA, Kruınıng, J, Bakker, M and Schalm, SW Immune response after vaccınation with recombınant vaccıne Antiviral Res 1985, Suppl I, 281-288

23 Iwarson, S Post-exposure prophylaxıs for hepatıtıs B active or passive? Lancet 1989, II, 146-148

24 Dienstag, J L, Werner, B G, Polk, B G et al Hepatitis B vaccine in health care personnel safety, Immunogenıcity and indicators of efficacy Ann Intern Med 1984, 101, 34-40

25 Shaw, FE Jr, Guess, HA, Roets, JM et al Effect of anatomic Injection site, age and smokıng on the immune response to hepatitıs B vaccination Vaccine $1989,7,425-430$

26 Zachoval, R, Jılg, W, Lorbeer, B, Schmıdt, M and Deınhardt, F Passive-active ımmunizatıon against hepatıtıs B $J$ Infect Dis 1984, 150, 112-117

27 Goudeau, A, Coursaget, P, Barın, F, Duboıs, F, Chıron, J-P, Denıs, $F$ and Diop Mar, I Prevention of hepatitis $B$ by active and passive-active immunization Viral Hepatitis 1981 international Symposium (Eds Szmuness $W$ Alter $H J$ and Maynard, JE) Franklın Institute Press, Phıladelphıa, 1982 pp 509-525

28 Szmuness, W, Stevens, CE, Oleszko, WR et al Passive-active Immunızation agaınst hepatitis $B$ immunogenicity studies in adult Americans Lancet 1981, i, 575-577

29 Wong, VCW Ip HMH Reesink, HW et al Prevention of the HBsAg carrier state in newborn infants of mothers who are chronic carriers of $\mathrm{HBsAg}$ and $\mathrm{HBeAg}$ by administration of hepatıtıs $\mathrm{B}$ vaccıne and hepatitıs B ımmunoglobulın Lancet 1984, ı, 921926

30 Lelıe, P N, Reesınk, HW, Grım, R, de Jong-van Manen, S Th and Reerınk-Brongers, EE Simultaneous passive and active ımmunızation against hepatitis $B$ Non-ınterference of hepatitıs $B$ immune globulın with the antıHBs response to reduced doses of heatinactivated hepatitis B vaccine Hepatology 1986, 6, 971-975

31 Stevens, CE, Taylor, PE, Tong, M J et al Yeast-recombınant hepatitis $B$ vaccine Efficacy with hepatitis $B$ immune globulin in prevention of perinatal hepatitis $\mathrm{B}$ virus transmissıon $J \mathrm{Am}$ 
Med Assoc 1987, 257, 2612-2616

32 Keller, SE, Weiss, JM, Schleifer, S J, Miller, NE and Steın, M Suppression of immunity by stress effect of graded series of stress on lymfocyte stimulation in the rat Science 1981, 213, 1397-1400

33 Ballieux, RE Stress and Immune response parameters and markers Breakdown in human adaptation to "stress Towards a multidiscipinary approach (Eds Ballieux, RE, Fielding, $\mathrm{FJ}$ and l'Abbate, A) Martınus Nighoff Publıshers, The Hague, 1984, pp $732-739$

34 Rose, NR, Friedman, $\mathrm{H}$ and Fahey, JL (Eds) Manual of clinical laboratory immunology, American Society (Microbiology) Wash-
Ington, DC, 1986

35 Kiecolt-Glaser, J K, Garner, W, Speıcher, C, Penn, G M, Hollıday, $\mathrm{J}$ and Glaser, R Psychosocial modifiers of Immunocompetence in medical students Psychosom Med 1984, 46, 7-14

36 Glaser, R, Kiecolt-Glaser, JK, Speıcher, CE and Hollıday, JE Stress, loneliness and changes in herpes virus latency $J$ Behav Med 1985, 8, 249-260

37 Marx J L The immune system "belongs in the body" Pervasive anatomical and biochemical links between the immune and nervous systems help explain how mood might influence disease susceptibility Science 1985, 227, 1190-1193 